\title{
PENURUNAN KADAR LOGAM BERAT LIMBAH CAIR INDUSTRI EMAS (PT. X) DI SURABAYA
}

\author{
Nyoman Puspa Asri ${ }^{*}$, Rachmad Abadi², Arfina Hasmawati², \\ dan Sita Alfian Mubarok ${ }^{2}$ \\ 1Jurusan Teknik Kimia, Fakultas Teknik, Universitas W.R. Supratman Surabaya \\ Jl. Arief Rachman Hakim No. 14 Surabaya 60111 \\ ${ }^{2} J u r u s a n$ Teknik Kimia, Fakultas Teknologi Industri, Institut Teknologi Adhitama Surabaya \\ Jl. Arief Rachman Hakim No. 100 Surabaya 60111 \\ Email: nyoman_puspaasri@yahoo.com
}

\begin{abstract}
Abstrak
Penelitian ini bertujuan untuk menurunkan kadar logam berat pada limbah cair industri emas (PT. X) di Surabaya. Limbah cair dari industri perhiasan emas sebagian besar merupakan limbah anorganik dengan kandungan asam yang cukup tinggi ( $\mathrm{pH}$ rendah). Metode yang digunakan adalah metode presipitasi (pengendapan) dengan beberapa variabel yaitu jenis bahan pengendap $\left(\mathrm{NaOH}\right.$ dan $\left.\mathrm{Ca}(\mathrm{OH})_{2}\right)$, $\mathrm{pH}$ larutan dan waktu pengendapan. Dari hasil penelitian diketahui bahwa dengan penambahan $\mathrm{Ca}(\mathrm{OH})_{2}$ maupun $\mathrm{NaOH}$, semakin tinggi $\mathrm{pH}$, maka semakin besar pula persen penurunan logam $\mathrm{Cu}, \mathrm{Ni}, \mathrm{Zn}$, dan Fe. Demikian pula dengan variabel waktu pengendapan maka semakin lama waktu pengendapan maka semakin besar persen penurunan logam $\mathrm{Cu}, \mathrm{Ni}, \mathrm{Zn}$, dan $\mathrm{Fe}$. pH optimum yang dapat menurunkan kadar logam $\mathrm{Cu}, \mathrm{Ni}, \mathrm{Zn}$ dan $\mathrm{Fe}$ adalah pada $\mathrm{pH}$ 12. Besarnya persen penurunan logam $\mathrm{Cu}, \mathrm{Ni}, \mathrm{Zn}$ dan $\mathrm{Fe}$ dengan penambahan presipitan $\mathrm{NaOH}$ berturut - turut adalah 99,993\%, 99,877\%, 99,946\% dan 99,935\%. Besarnya persen penurunan logam $\mathrm{Cu}, \mathrm{Ni}, \mathrm{Zn}$ dan $\mathrm{Fe}$ dengan penambahan presipitan $\mathrm{Ca}(\mathrm{OH})_{2}$ berturut-turut adalah 99,994\%, 99,936\%, $99,949 \%$ dan $99,941 \%$, sedangkan waktu pengendapan yang optimum adalah pada 30 menit. Berdasarkan hasil penelitian terlihat bahwa presipitan $\mathrm{Ca}(\mathrm{OH})_{2}$, lebih baik dibanding $\mathrm{NaOH}$.
\end{abstract}

Kata kunci: Logam berat, limbah cair, presipitasi

\begin{abstract}
This research has purpose to reduce heavy metal contain in liquid waste of gold industries (PT. X) in Surabaya. Most of liquid waste from gold jewellery industry is an inorganic waste with high acid composition (low $\mathrm{pH}$ ). The method being used is precipitation method with some variables such as type of presipitaior, $\mathrm{pH}$ of solution and time of precipitation. From the research's result with $\mathrm{Ca}(\mathrm{OH})_{2}$ and $\mathrm{NaOH}$, the higher the $\mathrm{pH}$, the higher the percentage removal of metal $\mathrm{Cu}, \mathrm{Ni}, \mathrm{Zn}$, and $\mathrm{Fe}$. The same result with variables of precipitation's time when the longer floculation time, the higher the percentage removal of metal $(\mathrm{Cu}, \mathrm{Ni}, \mathrm{Zn}$ and $\mathrm{Fe}$ ). The optimum $\mathrm{pH}$ that can decrease metal content $\mathrm{Cu}, \mathrm{Ni}, \mathrm{Zn}$ and $\mathrm{Fe}$, is 12 . The percentage of removal with additional $\mathrm{NaOH}$ in order are $99.93 \%, 99.77 \%, 99.46 \%$, and $99.35 \%$, with additional $\mathrm{Ca}(\mathrm{OH})_{2}$ are $99.94 \%, 99.936 \%, 99.949 \%, 99.941 \%$, meanwhile the optimum time of precipitation to decrease metal concentrate is 30 minute. So from the result the addition of $\mathrm{Ca}(\mathrm{OH})_{2}$ is much better than $\mathrm{NaOH}$.
\end{abstract}

Keywords: Heavy metals, liquid waste, presipitation

*korespondensi 


\section{Pendahuluan}

PT. X (industri perhiasan emas di Surabaya Timur) merupakan industri yang menghasilkan perhiasan dari bahan emas, dimana dalam proses pembuatan perhiasan tersebut menghasilkan limbah cair yang banyak mengandung logam berat. Apabila limbah ini langsung dibuang ke badan air maka dapat menimbulkan dampak negatif terhadap lingkungan sekitar.

Limbah industri PT. X ini memiliki kandungan logam-logam berat yang dapat disetarakan dengan limbah industri electroplating. Limbah cair dari industri perhiasan emas sebagian besar merupakan limbah anorganik dengan kandungan asam yang cukup tinggi.

Tabel 1. Karakteristik Limbah Cair PT. X

\begin{tabular}{lcccc}
\hline Komponen & $\mathbf{C u}$ & $\mathbf{N i}$ & $\mathbf{Z n}$ & $\mathbf{F e}$ \\
\hline $\begin{array}{l}\text { Kandungan } \\
\text { Logam } \\
\text { (ppm) }\end{array}$ & 29627,79 & 187,5 & 295,75 & 2562,79 \\
$\begin{array}{l}\text { Standard } \\
\text { Baku Mutu }\end{array}$ & 5 & 1 & 20 & 20 \\
\hline
\end{tabular}

Tabel di atas menunjukkan bahwa kandungan logam berat yang berasal dari limbah cair PT. X seperti logam $\mathrm{Cu}, \mathrm{Ni}, \mathrm{Zn}, \mathrm{Cd}$ dan $\mathrm{Fe}$, melebihi kadar maksimum baku mutu limbah cair electroplating, sehingga perlu untuk dilakukan pengolahan limbah cair tersebut untuk mengurangi kadar logam berat sebelum di buang ke badan air. Untuk menurunkan kadar logam tersebut, PT. X telah melakukan pengolahan limbah sebelum dibuang ke badan air dengan menggunakan metode presipitasi, yaitu dengan menambahkan $\mathrm{NaOH}$ sebagai bahan presipitan pada $\mathrm{pH}$ 8.5-10, namun kadar logam berat masih di atas ambang batas baku mutu yang diijinkan.

Limbah cair PT. X berasal dari proses refinery, proses bombing dan glundung, proses pencucian dan proses pengaturan warna dan bilasan. Rachmad dkk. telah melakukan penelitian pendahuluan menggunakan sampel air limbah sebanyak $200 \mathrm{~mL}$ menggunakan metode Jar-tes dengan menggunakan komposisi air limbah dari keempat proses di atas sebagai variabel, dengan penambahan $\mathrm{NaOH}$ pada $\mathrm{pH}$ sekitar 8,5-10. Hasil penelitian menunjukkan bahwa $\mathrm{pH}$ awal limbah adalah 2, sedangkan komposisi limbah terbaik adalah 13,37\% limbah dari bak penampung limbah I (proses refinery), 1,96\% limbah dari bak penampung limbah II (proses bombing dan glundung),
5,72\% limbah dari bak penampung limbah III (proses pencucian), 78,95\% limbah dari bak penampung limbah IV (proses pengaturan warna dan bilasan), dengan penurunan kadar logam berat berkisar antara 96-98\%. Roekmijati dkk. (2001), telah melakukan penelitian tentang "Presipitasi Bertahap Logam Berat Limbah Cair Industri Pelapisan Logam Menggunakan Larutan Kaustik Soda". Hasil penelitiannya menunjukkan bahwa dengan variabel $\mathrm{pH} \quad 4,6$ dan 8 tidak berpengaruh secara signifikan terhadap penurunan kadar logam berat $\mathrm{Cu}$ dan $\mathrm{Fe}$.

Dari latar belakang di atas, dapat diketahui bahwa kadar logam berat yang melebihi baku mutu pemerintah adalah logam $\mathrm{Cu}, \mathrm{Ni}, \mathrm{Zn}$ dan Fe sehingga dilakukan penelitian untuk menurunkan kadar logamlogam berat tersebut sampai sekecil mungkin dengan metode prespitasi. Banyak faktor yang mempengaruhi proses presipitasi, namun pada penelitian ini difokuskan pada variabel $\mathrm{pH}$, waktu pengendapan dan jenis presipitan. Jenis presipitan yang digunakan adalah $\mathrm{NaOH}$ dan $\mathrm{Ca}(\mathrm{OH})_{2}$. $\mathrm{Ca}(\mathrm{OH})_{2}$ digunakan sebagai pembanding $\mathrm{NaOH}$ yang selama ini digunakan dengan harapan didapat presipitan yang lebih efektif dan efisien.

Tujuan dari penelitian ini adalah untuk mendapatkan harga $\mathrm{pH}$ larutan dan waktu pengendapan yang memberikan persen penurunan logam $\mathrm{Cu}, \mathrm{Ni}, \mathrm{Zn}$ dan $\mathrm{Fe}$ yang paling besar. Di samping itu juga untuk mengetahui diantara dua presipitan yang digunakan mana yang lebih efisien.

Hasil penelitian ini diharapkan dapat digunakan sebagai referensi, sebagai bahan perbandingan maupun sebagi acuan bagi industri-industri yang sejenis dalam mengolah limbah cair terutama dalam penurunan logam berat yang terkandung didalamnya.

\section{Teori Dasar}

Pada dasarnya logam berat dalam air buangan dapat dipisahkan dengan berbagai cara yaitu dengan proses fisika, kimia dan biologi. Proses pengambilan logam berat yang terlarut dalam suatu larutan biasanya dilakukan dengan cara prespitasi, reverse osmosis, ion exchange dan adsorbsi.

Penurunan kandungan logam berat pada air limbah industri ini, dilakukan dengan proses fisik-kimia. Teknologi pengolahan air limbah yang mengandung logam-logam telah lama dikembangkan dan metode yang 
umumnya digunakan adalah menggunakan prinsip presipitasi.

Pengolahan limbah dengan metode presipitasi merupakan salah satu metode pengolahan limbah yang banyak digunakan untuk memisahkan logam berat dari limbah cair. Dalam metode presipitasi kimia dilakukan penambahan sejumlah zat kimia tertentu untuk mengubah senyawa yang mudah larut ke bentuk padatan yang tak larut. Tiap-tiap logam memiliki karakteristik $\mathrm{pH}$ optimum presipitasi tersendiri, yaitu $\mathrm{pH}$ pada saat logam tersebut memiliki kelarutan minimum. Oleh karena itu pada limbah yang mengandung beragam logam presipitasi dilakukan secara bertahap, yaitu dengan melakukan perubahan $\mathrm{pH}$ pada tiap tahapannya sehingga logam-logam tersebut dapat mengendap secara bertahap.

Presipitasi kimia adalah suatu prosedur standar untuk menyisihkan atau menurunkan kandungan logam berat dari air dan air limbah. Pembentukan presipitat sangat ditentukan oleh penambahan bahan kimia sebagai pengikat logam-logam. Dosis bahan kimia yang dibutuhkan relative sulit dihitung secara teoritis, umumnya ditentukan melalui percobaan dalam skala laboratorium. Percobaan dengan penentuan dosis bahan kimia untuk proses presipitasi atau koagulasi ini sering disebut sebagai Jar-Test. Adapun yang mempengaruhi percobaan dengan JarTest ini, antara lain :

1. Bahan kimia yang dipakai untuk menurunkan kadar logam berat

2. Penambahan dosis presipitan

3. $\mathrm{pH}$

4. Kecepatan pengadukan

5. Waktu pengendapan.

Penurunan kadar logam berat terutama tergantung pada dua faktor, yaitu :

1. Kelarutan teoritis yang membentuk spesies padatan terlarut sebagai fungsi dari konstanta kesetimbangan kelarutan, pH dan konsentrasi bahan pembentuk presipitat.

2. Pemisahan padatan dari larutan yang membawanya.

Logam-logam berat umumnya dipresipitasi sebagai hidroksidanya dengan penambahan Kapur $\mathrm{Ca}(\mathrm{OH})_{2}$ atau Soda Api $(\mathrm{NaOH})$ untuk menjaga minimum $\mathrm{PH}$ kelarutan. Ada beberapa jenis logam yang bersifat amfoter sebagaimana ditunjukkan pada Gambar 1. Kelarutan Chrom (Cr) dan Seng (Zn) secara teoritis minimum masingmasing pada pH 7,5 dan 10,2 menunjukkan suatu kenaikan signifikan dalam konsentrasi jika di atas atau di bawah nilai $\mathrm{pH}$ tersebut (Day dan Underwood, 1991).

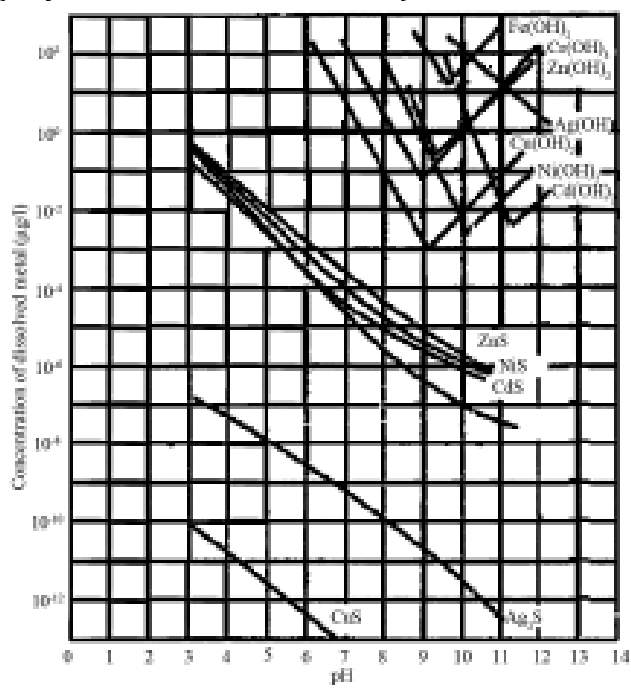

Gambar 1: Pengaruh $\mathrm{pH}$ pada logam berat sebagai Hidroksida

Pada beberapa keadaan faktor-faktor di atas dapat mengganggu proses presipitasi karena kelebihan ion-ion yang berbeda muatannya yang dapat menyebabkan presipitat tidak dapat mengendap atau dipisahkan dari air yang membawanya. Oleh karenanya diperlukan suatu tambahan bahan kimia yang membantu proses presipitasi. Bahan kimia ini disebut sebagai bahan kopresipitasi yang berfungsi untuk menyerap dan menggumpalkan. Logam yang bersifat kopresipitat adalah Alumunium hidroksida $\left(\mathrm{Al}(\mathrm{OH})_{3}\right)$ dan Feri hidroksida $\left(\mathrm{Fe}(\mathrm{OH})_{3}\right)$ (Eckenfelder, 1989).

Reaksi-reaksi Presipitasi hidroksida untuk semua logam-logam kationik (M) adalah sama dengan yang ditunjukkan dengan reaksi sebagai berikut:

$$
\begin{aligned}
& \mathrm{MCO}_{3}+\mathrm{Ca}(\mathrm{OH})_{2} \rightarrow \mathrm{M}(\mathrm{OH})_{2} \downarrow+\mathrm{CaCO}_{3} \downarrow \\
& \mathrm{MSO}_{4}+\mathrm{Ca}(\mathrm{OH})_{2} \rightarrow \mathrm{M}(\mathrm{OH})_{2} \downarrow+\mathrm{CaSO}_{4} \downarrow \\
& \mathrm{MCl}_{2}+\mathrm{Ca}(\mathrm{OH})_{2} \rightarrow \mathrm{M}(\mathrm{OH})_{2} \downarrow+\mathrm{CaCl}_{3} \downarrow \\
& \mathrm{MSO}_{4}+2 \mathrm{NaOH} \rightarrow \mathrm{M}(\mathrm{OH})_{2} \downarrow+\mathrm{NaSO}_{4} \downarrow \\
& \mathrm{MCO}_{3}+2 \mathrm{NaOH} \rightarrow \mathrm{M}(\mathrm{OH})_{2} \downarrow+\mathrm{NaCO}_{3} \downarrow \\
& \mathrm{MCl}_{2}+2 \mathrm{NaOH} \rightarrow \mathrm{M}(\mathrm{OH})_{2} \downarrow+\mathrm{NaCl}_{2} \downarrow
\end{aligned}
$$

Pemakaian kapur lebih menguntungkan daripada pemakaian soda api karena garam-garam kapur bersifat mengendap dan dapat bertindak sebagai kopresipitat. Kerugian pemakaian kapur adalah jumlah lumpur yang dihasilkan lebih banyak dibandingkan dengan penggunaan 
soda, tetapi lebih ekonomis karena harganya lebih murah dan mudah didapat.

Untuk presipitasi logam berat limbah cair dengan menggunakan kaustik soda, sebelumnya dilakukan penambahan $\mathrm{NaHSO}_{3}$ $40 \%$ untuk mengendapkan $\mathrm{Cr}(\mathrm{VI})$, karena $\mathrm{Cr}(\mathrm{VI})$ sukar mengendap dengan menggunakan kaustik. Logam Cr mengalami kenaikan proses penyisihan dengan meningkatnya volume presipitan. Logam $\mathrm{Cu}$, Fe dan Mn mengalami penurunan proses penyisihan logam dengan semakin besarnya volume presipitan. Proses penyisihan tertinggi untuk logam $\mathrm{Cr} 98,04 \%$ dicapai pada pH 8,2, Cu sebesar 99,94\% pada $\mathrm{pH} 8,5, \mathrm{Fe}$ sebesar $99,97^{\circ} \%$ pada $\mathrm{pH} 7$, sedangkan $\mathrm{Mn}$ sebesar 99,5\% pada pH 8,8 (Roekmijati dkk., 2001).

Logam berat dapat pula dipresipitasi sebagai sulfida dan karbonat seperti dalam kasus pengolahan limbah timah. Kelarutan sulfida dan karbonat umumnya lebih rendah daripada bentuk hidroksida, sehingga lebih sulit mencapai konsentrasi luaran yang diiinginkan.

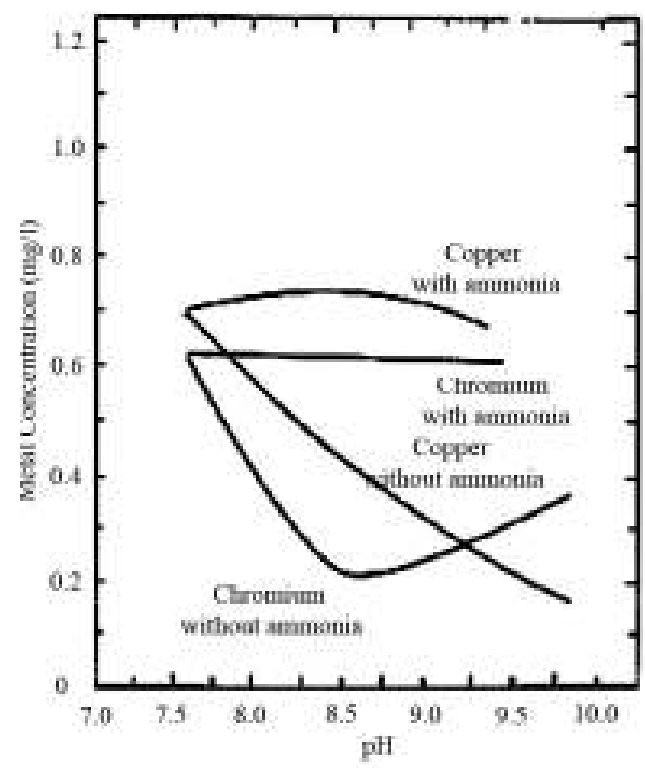

Gambar 2. Pengaruh pH dan amoniak pada kelarutan $\mathrm{Cu}$ dan $\mathrm{Cr}$.

Presipitasi karbonat baik untuk pengendapan logam $\mathrm{Pb}$ dan $\mathrm{Ni}$. Pengolahan limbah yang mengandung logam kadang kala memerlukan pengolahan pendahuluan untuk menghilangkan ion-ion pengganggu proses presipitasi logam. Sianida dan amoniak dapat membentuk senyawa kompleks dengan logam-logam dan mengganggu proses presipitasi. Sianida dapat dihilangkan dengan klorinasi alkali atau dengan oksidasi katalitik, akan tetapi limbah sianida yang mengandung nikel dan perak sulit untuk dihilangkan dengan metode klorinasi alkali. Amoniak bisa dihilangkan dengan aerasi khlorinasi titik retak. Kelarutan logam-logam dengan atau tanpa adanya amoniak sebagai fungsi $\mathrm{pH}$ dapat dilihat pada Gambar 2.

Pada presipitasi arsen dan besi, oksidasi mungkin memerlukan penggunaan klor atau permanganate. Untuk pengolahan limbah khrom, khrom heksavalensi $\left(\mathrm{Cr}^{6+}\right)$ harus direduksi terlebih dahulu menjadi khrom trivalent $\left(\mathrm{Cr}^{3+}\right)$ dan kemudian di presipitasi dengan kapur (Day dan Underwood, 1991).

\section{Metodologi}

Penelitian ini dilakukan melalui beberapa tahap meliputi persiapan sampel, percobaan dan analisis hasil. Penyiapan sampel sebanyak $200 \mathrm{~mL}$ dilakukan dengan mencampur keempat sumber limbah yaitu limbah dari proses refinery, limbah bombing dan glundung, proses pencucian, dan limbah pengaturan warna dan bilasan, masing masing 13,37\%, 1,96\%, 5,72\% dan 78,95\%. Proses presipitasi dengan metode Jar-Test dengan variabel $\mathrm{pH} 8,9,10,11$ dan 12, dengan pengadukan $100 \mathrm{rpm}$ selama 10 menit. Selanjutnya larutan polimer kuriflok ditambahkan sebanyak $10 \mathrm{~mL}$ dan melakukan pengadukan dengan kecepatan $60 \mathrm{rpm}$ selama 5 menit, serta menambahkan presipitan $\mathrm{NaOH}$ dan $\mathrm{Ca}(\mathrm{OH})_{2}$. Sampel didiamkan sesuai variabel waktu pengendapan yaitu 15, 20, 25 dan 30 menit. Analisis hasil dilakukan dengan metoda AAS. Persen penurunan kadar logam dihitung dengan rumus

$$
\% \text { Penurunan }=\frac{\text { Kadar awal }- \text { Kadar akhir }}{\text { Kadar awal }} \times 100 \%
$$

\section{Hasil dan Pembahasan}

Analisis kandungan logam berat pada sampel awal maupun setelah eksperimen dilakukan dengan metode AAS. Gambar 3, 4, 5, dan 6 menunjukkan pengaruh $\mathrm{pH}$ terhadap persen penurunan logam $\mathrm{Cu}, \mathrm{Ni}, \mathrm{Zn}$ dan $\mathrm{Fe}$ dengan penambahan presipitan $\mathrm{NaOH}$ pada waktu flokulasi sesuai dengan variabel (15, 20, 25 dan 30 menit). Dari gambar-gambar tersebut terlihat bahwa semakin besar $\mathrm{pH}$ maka persen penurunan logam semakin besar. Pada Gambar 4. terlihat bahwa dengan penambahan bahan presipitan $\mathrm{NaOH}$ dengan waktu pengendapan 30 menit, persen penurunan logam Fe pada $\mathrm{pH}$ 8, 9, 10, 11 dan 


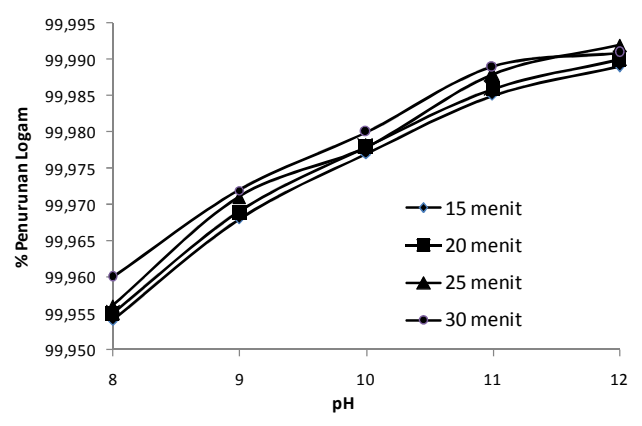

Gambar 3. Pengaruh pH terhadap persen penurunan logam $\mathrm{Cu}$ dengan presipitan $\mathrm{NaOH}$

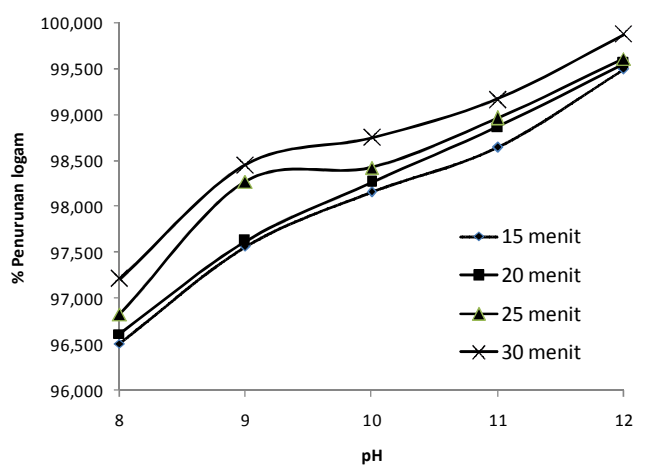

Gambar 4. Pengaruh pH terhadap persen penurunan logam $\mathrm{Ni}$ dengan presipitan $\mathrm{NaOH}$

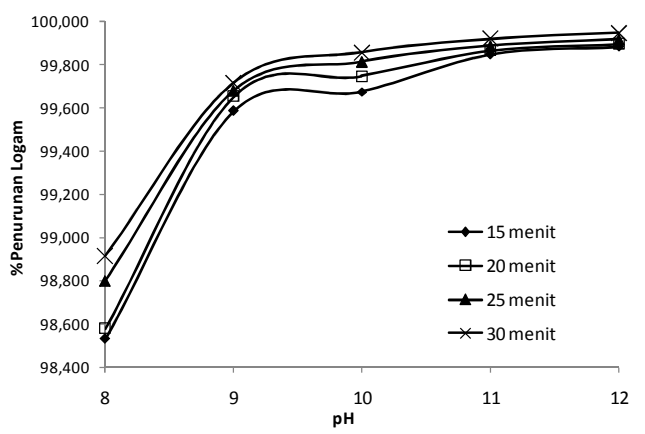

Gambar 5. Pengaruh pH terhadap persen penurunan Logam $\mathrm{Zn}$ dengan presipitan $\mathrm{NaOH}$

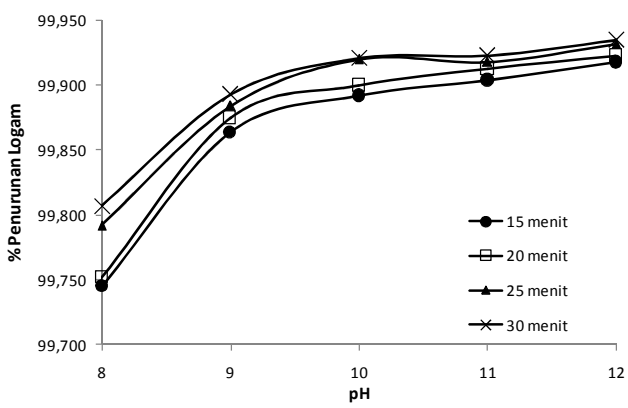

Gambar 6. Pengaruh pH terhadap persen penurunan logam $\mathrm{Fe}$ dengan presipitan $\mathrm{NaOH}$
99,921\%, 99,923\%, dan 99,935\%. Persen penurunan tertinggi adalah pada $\mathrm{pH} 12$ yaitu sebesar 99,935\%, hal ini menunjukkan bahwa semakin tinggi pH maka persen penurunan logam semakin besar. Literatur menyebutkan bahwa pH sangat berpengaruh pada saat ionion logam terikat dengan $\mathrm{OH}^{-}$yang ada pada presipitan $(\mathrm{NaOH})$ dan membentuk endapan. Reaksi ikatan ion-ion logam tersebut adalah sebagai berikut:

$$
\begin{aligned}
& \mathrm{Cu}^{2+}+2 \mathrm{NaOH} \rightarrow \mathrm{Cu}(\mathrm{OH})_{2} \downarrow+2 \mathrm{Na}^{+} \\
& \mathrm{Ni}^{2+}+2 \mathrm{NaOH} \rightarrow \mathrm{Ni}(\mathrm{OH})_{2} \downarrow+2 \mathrm{Na}^{+} \\
& \mathrm{Zn}^{2+}+2 \mathrm{NaOH} \rightarrow \mathrm{Zn}(\mathrm{OH})_{2} \downarrow+2 \mathrm{Na}^{+} \\
& \mathrm{Fe}^{2+}+2 \mathrm{NaOH} \rightarrow \mathrm{Fe}(\mathrm{OH})_{2} \downarrow+2 \mathrm{Na}^{+}
\end{aligned}
$$

Selain itu semakin tinggi $\mathrm{pH}$ maka semakin besar konsentrasi ion $\mathrm{OH}^{-}$sehingga harga hasil kali kelarutan ion-ion $\left[\mathrm{Cu}^{2+}\right]\left[\mathrm{OH}^{-}\right]^{2}>$ Ksp $\mathrm{Cu}(\mathrm{OH})_{2}$, dan mengakibatkan semakin banyak $\mathrm{Cu}$ yang mengendap. Kondisi ini berlaku juga untuk logam-logam lainnya.

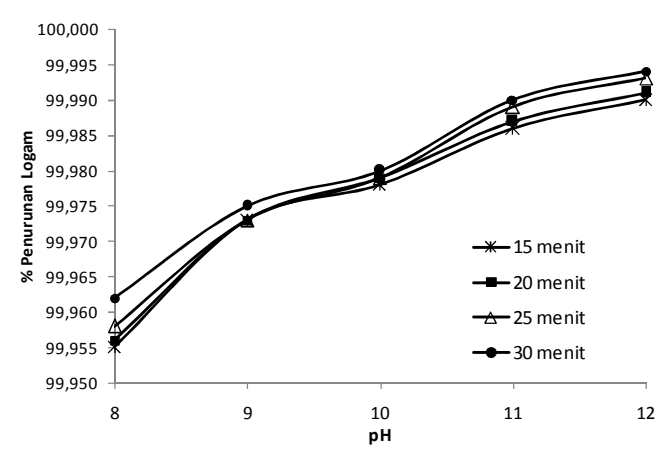

Gambar 7. Pengaruh pH terhadap persen penurunan logam $\mathrm{Cu}$ dengan presipitan $\mathrm{Ca}(\mathrm{OH})_{2}$

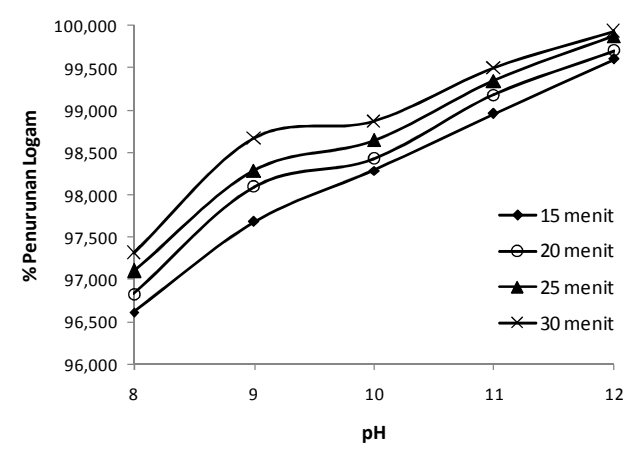

Gambar 8. Pengaruh pH terhadap persen penurunan logam $\mathrm{Ni}$ dengan presipitan $\mathrm{Ca}(\mathrm{OH})_{2}$

Gambar 7, 8, 9, dan 10 menunjukkan pengaruh $\mathrm{pH}$ terhadap persen penurunan logam $\mathrm{Cu}, \mathrm{Ni}, \mathrm{Zn}$ dan $\mathrm{Fe}$ dengan penambahan 
presipitan $\mathrm{Ca}(\mathrm{OH})_{2}$ dengan variabel waktu pengendapan $(15,20,25,30$ menit). Gambar tersebut menunjukkan bahwa semakin besar pH maka persen penurunan masing-masing logam semakin besar.

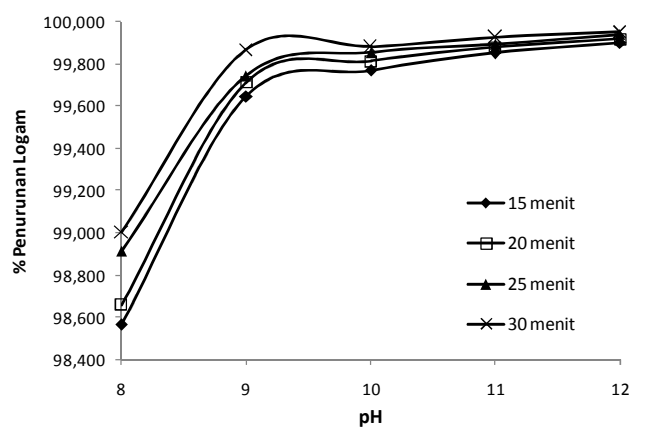

Gambar 9. Pengaruh pH terhadap persen penurunan logam $\mathrm{Zn}$ dengan presipitan $\mathrm{Ca}(\mathrm{OH})_{2}$

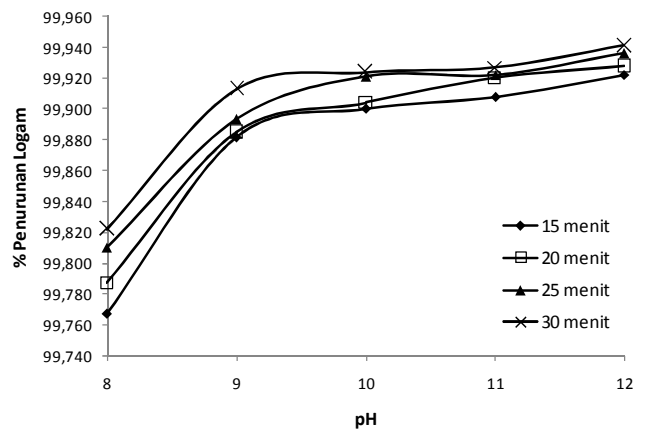

Gambar 10. Pengaruh pH terhadap persen penurunan logam $\mathrm{Fe}$ dengan presipitan $\mathrm{Ca}(\mathrm{OH})_{2}$

Pada Gambar 10 terlihat bahwa persen penurunan tertinggi adalah pada $\mathrm{pH} 12$ yaitu sebesar 99,941\%, hal ini menunjukkan bahwa semakin tinggi $\mathrm{pH}$ maka persen penurunan logam semakin besar. Dalam literatur menyebutkan bahwa $\mathrm{pH}$ sangat berpengaruh pada saat ion - ion logam terikat dengan $\mathrm{OH}^{-}$ yang ada pada presipitan $(\mathrm{NaOH})$ dan membentuk endapan. Reaksi ikatan ion-ion logam tersebut adalah sebagai berikut:

$\mathrm{Cu}^{2+}+\mathrm{Ca}(\mathrm{OH})_{2} \rightarrow \mathrm{Cu}(\mathrm{OH})_{2} \downarrow+\mathrm{Ca}^{2+}$

$\mathrm{Ni}^{2+}+\mathrm{Ca}(\mathrm{OH})_{2} \rightarrow \mathrm{Ni}(\mathrm{OH})_{2} \downarrow+\mathrm{Ca}^{2+}$

$\mathrm{Zn}^{2+}+\mathrm{Ca}(\mathrm{OH})_{2} \rightarrow \mathrm{Zn}(\mathrm{OH})_{2} \downarrow+\mathrm{Ca}^{2+}$

$\mathrm{Fe}^{2+}+\mathrm{Ca}(\mathrm{OH})_{2} \rightarrow \mathrm{Fe}(\mathrm{OH})_{2} \downarrow+\mathrm{Ca}^{2+}$

Gambar 11 menunjukkan bahwa persen penurunan terbesar pada $\mathrm{pH} 12$ dengan waktu pengendapan 30 menit adalah logam $\mathrm{Cu}$ baik dengan menggunakan presipitan $\mathrm{NaOH}$ maupun $\mathrm{Ca}(\mathrm{OH})_{2}$. Besarnya persen penurunan hampir mendekati $100 \%$ yaitu 99,993\% dengan menggunakan bahan presipitan $\mathrm{Ca}(\mathrm{OH})_{2}$ dan 99,990\% dengan menggunakan presipitan $\mathrm{NaOH}$. Terlihat bahwa logam $\mathrm{Cu}$ sudah mengendap sempurna pada pH 12, hal ini terjadi karena cupri oksida memiliki kelarutan minimum pada $\mathrm{pH} 9,0$ yaitu sebesar $10 \mu \mathrm{g} / \mathrm{L}$ (Haas dan Vamos, 1992) sehingga untuk mendapatkan persen penurunan logam $\mathrm{Cu}$ yang besar diperlukan pH yang lebih besar daripada pH kelarutan minimumnya.

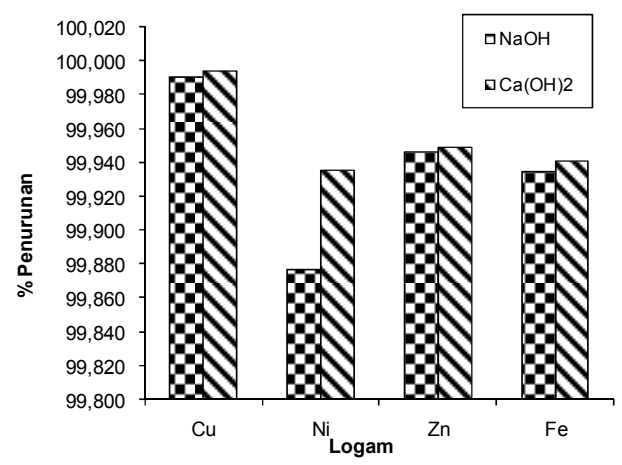

Gambar 11. persen Penurunan logam $\mathrm{Cu}$, $\mathrm{Ni}$, Zn dan Fe dengan presipitan $\mathrm{NaOH}$ dan $\mathrm{Ca}(\mathrm{OH})_{2}$ pada waktu 30 menit dan pH 12.

Persen penurunan logam $\mathrm{Ni}$, Fe, dan $\mathrm{Zn}$ berturut-turut yaitu 99,877\%, 99,941\%, $99,949 \%$ dengan presipitan $\mathrm{NaOH}$ dan 99,936\%, 9,946\%, 9,946\% dengan presipitan $\mathrm{Ca}(\mathrm{OH})_{2}$. Penurunan logam ini lebih kecil dibandingakan dengan penurunan logam $\mathrm{Cu}$. Hal ini disebabkan karena logam-logam tersebut mempunyai $\mathrm{pH}$ kelarutan minimum yang lebih besar (pH Ni =10-11; $\mathrm{pH} \mathrm{Fe}=10$; $\mathrm{pH} \mathrm{Zn}=10,5)$ dari pada $\mathrm{pH}$ kelarutan minimum $\mathrm{Cu}(\mathrm{pH}=9)$ sehingga untuk mengendapkan logam-logam tersebut dibutuhkan $\mathrm{pH}$ yang lebih tinggi daripada $\mathrm{pH}$ $\mathrm{Cu}$. Dari Gambar 11 juga terlihat bahwa penambahan presipitan kapur $\mathrm{Ca}(\mathrm{OH})_{2}$ lebih bagus dibanding dengan menggunakan kaustic soda $(\mathrm{NaOH})$ dalam mengurangi kadar logam, hal itu disebabkan kapur mengendapkan logam lebih cepat dan dapat bertindak sebagai kopresipitat (Haas dan Vamos, 1992).

Reaksi-reaksi Presipitasi hidroksida untuk semua logam-logam kationik (M) adalah sama dengan yang ditunjukkan dengan reaksi sebagai berikut:

$\mathrm{MCO}_{3}+\mathrm{Ca}(\mathrm{OH})_{2} \rightarrow \mathrm{M}(\mathrm{OH})_{2}+\mathrm{CaCO}_{3} \downarrow$

$\mathrm{MSO}_{4}+\mathrm{Ca}(\mathrm{OH})_{2} \rightarrow \mathrm{M}(\mathrm{OH})_{2}+\mathrm{CaSO}_{4} \downarrow$ 
$\mathrm{MCl}_{2}+\mathrm{Ca}(\mathrm{OH})_{2} \rightarrow \mathrm{M}(\mathrm{OH})_{2}+\mathrm{CaCl}_{2} \downarrow$

$\mathrm{MCO}_{3}+2 \mathrm{NaOH} \rightarrow \mathrm{M}(\mathrm{OH})_{2}+\mathrm{CaCO}_{3} \downarrow$

$\mathrm{MSO}_{4}+\mathrm{Ca}(\mathrm{OH})_{2} \rightarrow \mathrm{M}(\mathrm{OH})_{2}+\mathrm{CaSO}_{4} \downarrow$

$\mathrm{MCl}_{2}+\mathrm{Ca}(\mathrm{OH})_{2} \rightarrow \mathrm{M}(\mathrm{OH})_{2}+\mathrm{CaCl}_{2} \downarrow$

Perbedaan penambahan presipitan $\mathrm{NaOH}$ dengan $\mathrm{Ca}(\mathrm{OH})_{2}$ dari segi effisiensi biaya maupun operasionalnya ditunjukkan dengan tabel di bawah :

Tabel 2. Perbandingan koagulan $\mathrm{NaOH}$ dan $\mathrm{Ca}(\mathrm{OH})_{2}$ (Eckenfelder, 1989)

\begin{tabular}{lll}
\hline Parameter & NaOH & $\mathbf{C a}(\mathbf{O H})_{2}$ \\
\hline $\begin{array}{l}\text { Biaya operasional } \\
\text { Lumpur yang }\end{array}$ & Mahal & Murah \\
dihasilkan & Sedikit & Banyak \\
$\begin{array}{l}\text { Kecepatan } \\
\text { pengendapan }\end{array}$ & Lambat & Cepat \\
\hline
\end{tabular}

Dari Tabel 2 di atas terlihat bahwa kerugian menggunakan kapur adalah jumlah lumpur yang dihasilkan lebih banyak dibandingkan dengan penggunaan $\mathrm{NaOH}$, tetapi Lumpur yang dihasilkan sebagai limbah padat dapat diolah lagi menjadi Paving. Secara ekonomi harga kapur lebih murah dibandingkan dengan $\mathrm{NaOH}$.

Dari penelitian yang telah dilakukan oleh Roekmijati dkk. (2001), dalam penurunan logam berat $\mathrm{Cu}$ dan $\mathrm{Fe}$ dengan variable $\mathrm{pH} 4,6$ dan 8 tidak begitu berpengaruh terhadap penurunan kadar logam karena $\mathrm{pH}$ minimal dari kedua logam tersebut adalah pada pH 10 untuk logam $\mathrm{Cu}$ dan 12 untuk logam Fe. Penelitian ini menggunakan variabel pH 8, 9, 10, 11 dan 12 untuk menentukan $\mathrm{pH}$ optimum dari masing masing logam. Dari hasil penelitian ini didapatkan bahwa $\mathrm{pH}$ optimum untuk logam $\mathrm{Cu}$ dan Fe ada di atas pH 12.

Gambar 3-10 menunjukan bahwa semakin lama waktu pengendapan maka persen penurunan logam semakin besar. Persen penurunan logam optimum dicapai pada waktu 30 menit untuk presipitan $\mathrm{Ca}(\mathrm{OH})_{2}$ maupun $\mathrm{NaOH}$. Hal ini disebabkan bahwa semakin lama waktu pengendapan maka ikatan-ikatan logam dengan presipitan akan semakin banyak terbentuk, yang mana ikatan-ikatan logam ini akan membentuk flokflok dan mengendap, sehingga logam yang terlarut dalam air semakin kecil dan persen penurunan logamnya akan semakin besar.

\section{Kesimpulan}

Dari penelitian yang telah dilakukan dapat ditarik kesimpulan sebagai berikut:

1. Persen penurunan terbesar pada $\mathrm{pH}$ dan waktu flokulasi optimum dengan penambahan presipitan $\mathrm{NaOH}$ adalah logam $\mathrm{Cu}$ dengan persen penurunan sebesar 99,993\%. Sedangkan persen penurunan terbesar pada $\mathrm{pH}$ dan waktu flokulasi optimum dengan penambahan presipitan $\mathrm{Ca}(\mathrm{OH})_{2}$ adalah logam $\mathrm{Cu}$ dengan persen penurunan sebesar 99,994\%.

2. Waktu optimum yang dicapai oleh presipitan $\mathrm{NaOH}$ dan $\mathrm{Ca}(\mathrm{OH})_{2}$ dalam mengendapakan logam-logam adalah 30 menit.

3. Penambahan presipitan $\mathrm{Ca}(\mathrm{OH})_{2}$ lebih baik dibandingkan $\mathrm{NaOH}$ karena menghasilkan persen penurunan logam $\mathrm{Cu}, \mathrm{Ni}, \mathrm{Zn}$ dan $\mathrm{Fe}$ lebih besar dan dari segi effisiensi biaya maupun pengolahannya.

\section{Daftar Pustaka}

Day, R. A. Jr.; Underwood, A. L., Analisa Kimia Kuantitatif, Edisi 4, Penerbit Erlangga, Jakarta, 1991.

Eckenfelder, W. W., Jr., Industrial Water Pollution Control, 2nd Ed., McGraw-Hill International, Singapore, 1989.

Haas, C. N.; Vamos, R. J., Hazardous and Industrial Waste Treatment, Prentice Hall, Engelwood Cliffs, New Jersey, 1992.

Roekmijati, W. S.; Praswasti PDK. W.; Yulianti, Presipitasi Bertahap Logam Berat Limbah Cair Industri Pelapisan Logam Menggunakan Larutan Kaustik Soda, Jurusan Teknik Gas dan Petrokimia, Fakultas Teknik, Universitas Indonesia, 2001, http://www.chemeng.ui.ac.id (akses Juli 2008).

Patterson, J. W., Industrial Wasterwater Treatment Technology, $2^{\text {nd }}$ Edition, McGrawHill International, Singapore, 1989. 